\title{
Evaluation of Law Enforcement Agents' Potential Exposures during a Raid of a Clandestine "Spice" Lab
}

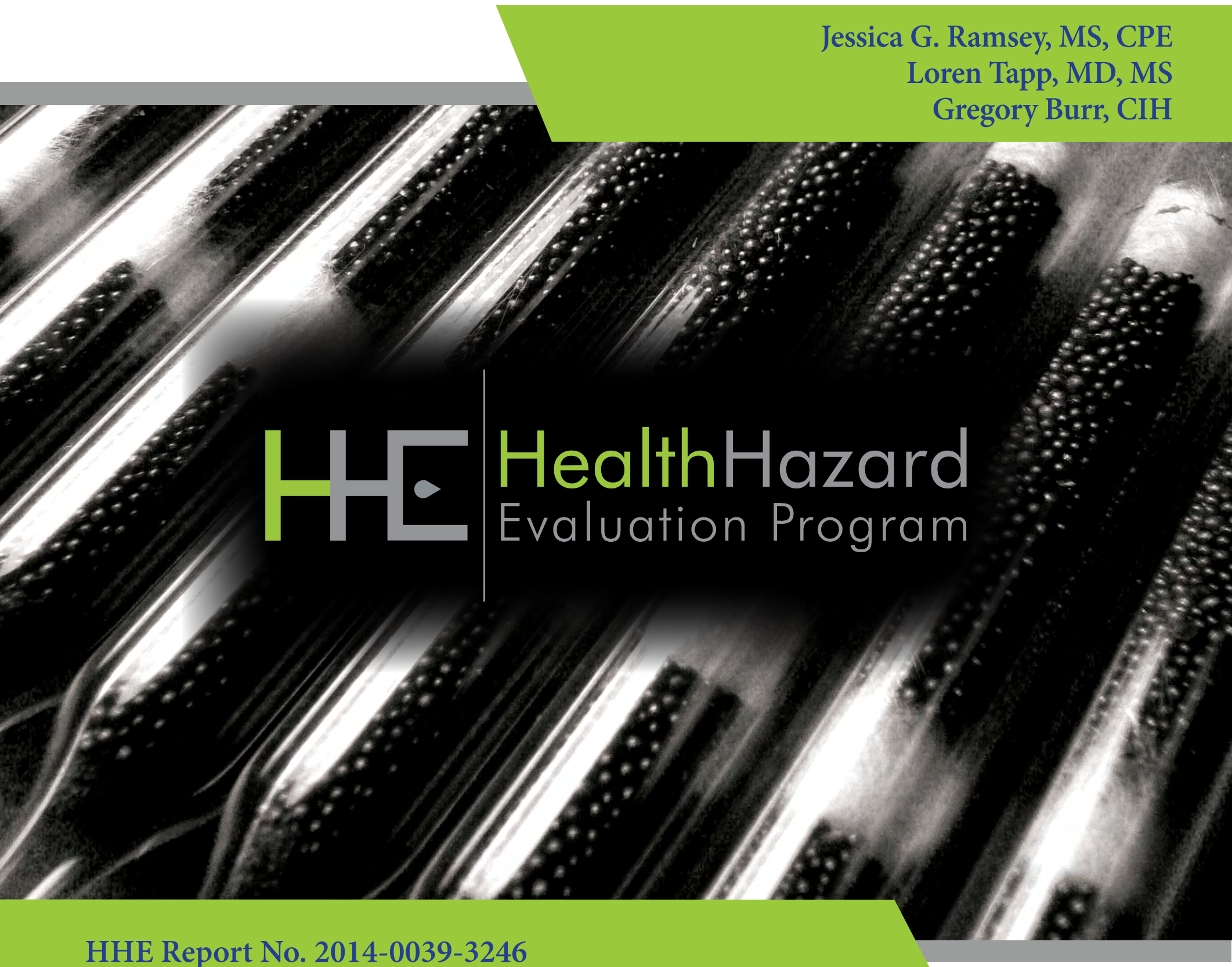

HHE Report No. 2014-0039-3246

March 2016

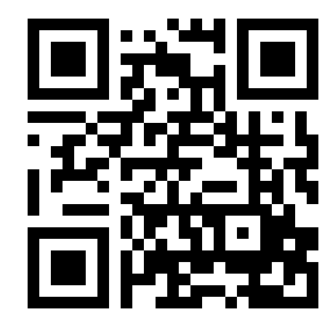

U.S. Department of Health and Human Services Centers for Disease Control and Prevention

National Institute for Occupational Safety and Health

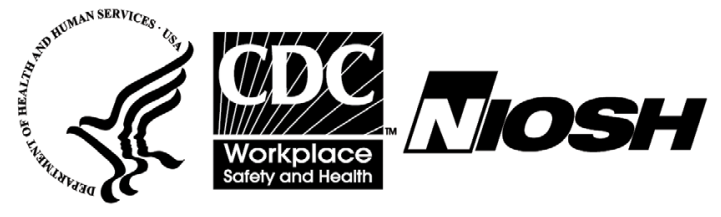




\section{Contents}

Highlights.

Abbreviations ...................................... iii

Introduction ............................................ 1

Methods............................................. 2

Results ............................................... 4

Discussion ......................................... 11

Conclusions....................................... 12

Recommendations.......................... 13

Appendix A..........................................16

Appendix B.............................................. 18

Appendix C.............................................19

Appendix D.....................................22

References................................................26

Acknowledgements............................. 31

The employer is required to post a copy of this report for 30 days at or near the workplace(s) of affected employees. The employer must take steps to ensure that the posted report is not altered, defaced, or covered by other material.

The cover photo is a close-up image of sorbent tubes, which are used by the HHE Program to measure airborne exposures. This photo is an artistic representation that may not be related to this Health Hazard Evaluation. Photo by NIOSH. 


\section{Highlights of this Evaluation}

The Health Hazard Evaluation Program received a request from a manager at a federal law enforcement agency. Law enforcement agents were concerned about their potential exposures to synthetic cannabinoids and other compounds during raids of clandestine spice labs. The agents were also concerned about exposures when they processed evidence at their office.

\section{What We Did}

- We watched agents raid a spice lab in December 2013.

- We collected urine from employees to check for AB-PINACA, a synthetic cannabinoid, and its breakdown products (also called metabolites). We also checked for mitragynine. This chemical is a plant material with opiumlike effects in humans.

- We took surface wipe samples in the spice lab and in the agency's office. We tested the samples for AB-PINACA and mitragynine.

- We took air samples for volatile organic compounds, AB-PINACA, and mitragynine. We sampled during the raid and in the agency's office during evidence processing.

- We used questionnaires to ask employees about their work history and work-related symptoms.

- We looked at the use of personal protective equipment by the agents.

- We checked the ventilation system to see if it was designed for evidence handling and processing.

\section{What We Found}

- We found AB-PINACA, its breakdown products, and/or mitragynine in the urine of six of nine agents after the raid. These compounds were not present in any urine samples before the raid.

- One surface wipe sample from the spice lab had a detectable amount of AB-PINACA.

- We found no airborne AB-PINACA or mitragynine in the spice lab or in the agency's office.

- We found very low levels of airborne volatile organic compounds in the spice lab and in the agency's office.

- About half of the agents reported symptoms when handling synthetic cannabinoids.

- Most of the agents did not use gloves when handling evidence bags in the agency's office. 
- The agency did not provide hand washing supplies for the agents' use in the field.

- The agency's office and its ventilation system were not designed to contain or control contaminants from the evidence.

- Agents inconsistently used gloves and protective clothing. Their practices could expose them to contaminants and spread contamination.

\section{What the Employer Can Do}

- Store and handle evidence in the northeast corner of the seventh floor. This area was on a separate ventilation system from the remainder of the seventh floor.

- Provide office ventilation separate from the ventilation system for evidence processing, evidence storage, and laboratories.

- Provide a locker room and shower for agents.

- Provide disposable protective clothing for all agents working in potentially contaminated areas or when handling potentially contaminated items.

- Provide hand-washing supplies for agents during field assignments.

- Train agents in work practices, hygiene, and use of personal protective equipment that will prevent exposure to potentially contaminated evidence.

\section{What Agents Can Do}

- Wear protective gloves and clothing when handling potentially contaminated items.

- Put on and take off protective equipment properly.

- Do not eat or drink around potentially contaminated items in the field or in the office.

- Wash your hands after handling potentially contaminated items, even if gloves are used. 


\section{Abbreviations}

$\begin{array}{ll}\mu \mathrm{g} / 100 \mathrm{~cm}^{2} & \text { Microgram per } 100 \text { square centimeter } \\ \text { ACGIH }{ }^{8} & \text { American Conference of Governmental Industrial Hygienists } \\ \text { CFR } & \text { Code of Federal Regulations } \\ \text { DEA } & \text { Drug Enforcement Administration } \\ \text { ELISA } & \text { Enzyme-linked immunosorbent assay } \\ \text { LC-MS/MS } & \text { Liquid chromatography-tandem mass spectrometry } \\ \text { LLOQ } & \text { Lower limit of quantification } \\ \mathrm{mg} / \mathrm{m}^{3} & \text { Milligram per cubic meter } \\ \text { MIK } & \text { Methyl isopropyl ketone } \\ \mathrm{mL} & \text { Milliliter } \\ \text { MPK } & \text { Methyl propyl ketone } \\ \text { ND } & \text { Not detected } \\ \text { ng/mL } & \text { Nanogram per milliliter } \\ \text { NIOSH } & \text { National Institute for Occupational Safety and Health } \\ \text { OEL } & \text { Occupational exposure limit } \\ \text { OSHA } & \text { Occupational Safety and Health Administration } \\ \text { PEL } & \text { Permissible exposure limit } \\ \text { ppm } & \text { Parts per million } \\ \text { REL } & \text { Recommended exposure limit } \\ \text { TLV } ® & \text { Threshold limit value } \\ \text { TWA } & \text { Time-weighted average } \\ \text { VOC } & \text { Volatile organic compound }\end{array}$


This page left intentionally blank 


\section{Introduction}

The Health Hazard Evaluation Program received a request from a manager at a federal law enforcement agency. Law enforcement field agents (agents) were concerned about their potential exposures to synthetic cannabinoids and other compounds during unannounced investigations (raids) of clandestine spice labs. They also were concerned about synthetic drug exposures when they processed the evidence in their office.

In this report "spice" refers to manufactured chemical mixtures that produce experiences similar to marijuana (cannabis) and that are marketed as a "legal" high. Synthetic cannabinoids are chemicals with psychoactive properties. The Synthetic Drug Abuse Prevention Act, part of the U.S. Food and Drug Administration Safety and Innovation Act of 2012 (Public Law 112144), places 26 types of synthetic cannabinoids and cathinones (a plant stimulant with effects similar to those of amphetamine) into Schedule 1 of the Controlled Substances Act. Because these substances have been designated as Schedule 1, federal law enforcement agencies have exercised their authority in controlling manufacturing, stopping production, and collecting evidence.

We accompanied the agents during a raid in December 2013. Before the raid, we met with agency managers and agents to discuss their concerns. We observed workplace conditions and work processes and practices during the raid and at the agency's office where agents sorted and processed the evidence. We sent a letter summarizing our activities and initial observations to the manager and agent's representatives in January 2014. In May and June 2014, we sent a letter to each of the nine agents we tested notifying them of their air sample results for volatile organic compounds (VOCs) and psychoactive compounds. We sent letters summarizing these results to the manager and the agent's representatives at the same time. In June 2015, we sent the manager and agent's representatives an interim report that discussed the results of the air and surface samples and our evaluation of the office ventilation system. In that same month we also sent each of the nine agents we tested a letter notifying them of their urine sample results for psychoactive compounds. We sent a summary letter to the manager and the agent's representatives at the same time.

\section{Background}

On the basis of their past law enforcement experience and background information on this particular spice lab, the agents suspected that the operators were likely dissolving synthetic cannabinoids in ethanol and spraying the solution onto dried raspberry or strawberry plant material. The treated plant material would be air dried on baking sheets and then packaged in heat-sealed foil packets. This background information proved to be accurate. Information provided to us by the U.S. Drug Enforcement Administration (DEA), suggested that the psychoactive compounds likely present in this spice lab were a synthetic cannabinoid called AB-PINACA and mitragynine.

During the raid, the agents collected evidence, including suspected treated and untreated plant material, sealed spice packets, baking sheets, and paper records. The agents collected sealed packages of kratom, a designer drug of abuse that contains the active ingredient 
mitragynine. Mitragynine, an indole alkaloid, produces psychoactive effects on the user. After hand-writing descriptions of the item in an evidence log, agents placed the evidence in plastic or paper bags before taking the bags back for storage in the evidence room at the agency's office. On the days following the raid, the agents removed evidence bags from the evidence room and took them to an adjacent equipment room or to a nearby conference room for sorting and cataloging.

\section{Methods}

The objectives of this evaluation were the following:

1. Evaluate agents' potential airborne and skin exposures to chemicals including psychoactive compounds.

2. Analyze agents' urine for synthetic cannabinoids and other psychoactive compounds.

3. Determine the prevalence of symptoms consistent with exposure to psychoactive compounds.

\section{Air and Surface Wipe Sampling}

We evaluated agents' potential exposures to VOCs in two steps. We took six area air samples in the spice lab and at the agency's office using thermal desorption tubes following National Institute for Occupational Safety and Health (NIOSH) Method 2549 [NIOSH 2016]. We screened these samples to identify chemicals for further analysis. We also took 16 personal and 4 area air samples on charcoal tubes following NIOSH Method 1500 [NIOSH 2016]. We analyzed the charcoal tube samples for acetone, ethanol, toluene, methyl isopropyl ketone (MIK), methyl propyl ketone (MPK), xylene, benzene, cyclohexanone, diisobutyl ketone, ethylbenzene, and methyl butyl ketone.

To evaluate exposures to AB-PINACA and mitragynine we took personal and area air samples on polytetrafluoroethylene filters. We analyzed the samples by gas chromatographymass spectrometry following method conditions and using an extraction solvent (methanol) recommended by the DEA (Appendix C). Because this is not a validated method, the results we obtained should be considered semi-quantitative and the reported minimum detectable and minimum quantifiable concentrations should be considered estimates. However, a limited study of extraction and recovery efficiency was conducted (Appendix C). On the basis of our limited study and other quality control parameters, it appears that methanol may not be the best media/extraction solvent combination.

We took 17 surface wipe samples in the spice lab and at the agency's office. For each wipe sample we wore clean nitrile gloves to avoid cross contamination and sampled a 100-square-centimeter surface area using a disposable cardboard template, when possible. For uneven or irregular surfaces, we estimated the sample area. We took wipe samples using Puritan ${ }^{\circledR}$ sterile foam-tipped applicators (macrofoam swabs), AlphaWipes ${ }^{\circledR}$, and Puritan cotton swabs. The samples were wetted with either deionized water (macrofoam swabs and AlphaWipes) or a buffer solution (cotton swabs). We used different sampling techniques side-by-side for some samples because we were uncertain which method might be best. We analyzed the surface wipe samples for AB-PINACA and mitragynine using gas 
chromatography-mass spectrometry following the method conditions and extraction solvent used by the DEA (Appendix C).

\section{Workplace Observations}

We looked at the work activities of agents, including their initial entry into the raided spice lab, the collection and bagging of evidence in plastic and paper bags, and the transfer of evidence to the office for additional processing and storage. In all locations, we observed the use of personal protective equipment.

\section{Ventilation}

We looked for evidence of water damage, water incursion, visible mold, and other potential indoor environmental quality problems in the agency's offices. We visually inspected the rooftop air handling unit that provided ventilation for the floor where the offices were located. We evaluated air distribution to the offices by measuring airflow with a TSI AccuBalance ${ }^{\circledR}$ Model 8371 ventilation flow hood. We also spoke with the building's facilities managers about the design and maintenance of the ventilation system.

\section{Questionnaire}

We asked agents participating in the raid to complete a short questionnaire the day after the raid. The questionnaire contained questions about demographics, work history, medical history, history of smoking and alcohol use, and health symptoms that could be related to workplace psychoactive drug exposures.

\section{Biological Monitoring}

Each agent on whom we collected an air sample provided urine samples. We asked agents to provide five samples over 3 consecutive days. We collected urine samples at the following times:

1. Day 1 (baseline): in the afternoon of the day before entry and search of the spice lab

2. Day 2 (post-shift): immediately after the work shift during which entry, search, handling, and processing evidence of synthetic cannabinoids and other psychoactive drugs occurred

3. Day 2 (bedtime): at bedtime the same day of the raid

4. Day 3 (morning): the next morning before sorting evidence

5. Day 3 (post-shift): at the end of the shift after sorting evidence

We used two methods to measure the amount of AB-PINACA and mitragynine in all urine samples. The first was a screening test that uses an enzyme-linked immunosorbent assay (ELISA) method (Appendix C). The second was a liquid chromatography-tandem mass spectrometry (LC-MS/MS) method (Appendix C), which is considered to be a more accurate test. We also used the LC-MS/MS test to measure two AB-PINACA metabolites, ABPINACA-(4-hydroxypentyl) and AB-PINACA N-pentanoic acid. Levels of these metabolites tell us how much of the original substance entered the body. The manufacturer of the AB- 
PINACA ELISA method determined a cut-off of 5 nanograms per milliliter $(\mathrm{ng} / \mathrm{mL})$ to indicate a positive AB-PINACA result. There are no other biological exposure limits or reference ranges for these substances, and we do not know the levels at which health effects may occur.

\section{Results}

\section{Air and Surface Wipe Sampling}

We compared the personal air results for VOCs to occupational exposure limits (OELs) set by the Occupational Safety and Health Administration (OSHA), NIOSH, and the American Conference of Governmental Industrial Hygienists (ACGIH®). Employers are required by law to keep exposures below the OSHA limits. An OEL is meant to be the amount of a substance that most employees can be exposed to without harm. There are no OELs for AB-PINACA and mitragynine.

Appendix D discusses health effects of acetone and ethanol, the main VOCs that were present in quantifiable concentrations in the personal and area air samples. The OELs and personal sample results for acetone, ethanol, and the other four VOCs found in measureable amounts are presented in Table 1. The concentrations of these six VOCs in the personal air samples ranged from not detected to 1.3 parts per million ( $\mathrm{ppm}$ ). All VOC concentrations were well below their lowest OELs (Table 1). We also analyzed for the following chemicals, but none were found. The minimum detectable concentrations are shown in parentheses:

- benzene (0.005 ppm)

- cyclohexanone (0.01 ppm)

- diisobutyl ketone (0.004 ppm)

- ethylbenzene $(0.004 \mathrm{ppm})$

- methyl butyl ketone (0.004 ppm)

We took two area air samples and analyzed them for the same VOCs as in the personal air samples. We took the area air samples in the conference room and in the equipment room when agents handled the bagged evidence. We found low concentrations of acetone (0.02-0.09 ppm), ethanol (0.02-0.2 ppm), toluene (0.002 ppm), and MIK (0.002 ppm). We did not find benzene, cyclohexanone, diisobutyl ketone, ethylbenzene, methyl butyl ketone, MPK, or xylene $(<0.01 \mathrm{ppm})$. 
Table 1. Results of personal air sample concentrations for VOCs, in ppm*

\begin{tabular}{|c|c|c|c|c|c|c|c|c|}
\hline Day & Location & Samples & Acetone & Ethanol & Toluene & MIK & MPK & Xylene \\
\hline 1 & $\begin{array}{l}\text { Spice } \\
\text { lab }\end{array}$ & 6 & $\begin{array}{l}0.012 \text { to } \\
0.17\end{array}$ & $\begin{array}{l}0.34 \text { to } \\
1.3\end{array}$ & $\begin{array}{c}\text { ND† to } \\
0.020\end{array}$ & ND & $\begin{array}{l}\text { ND to } \\
(0.0083) \ddagger\end{array}$ & ND \\
\hline 2 & $\begin{array}{l}\text { Agency } \\
\text { office }\end{array}$ & 5 & $\begin{array}{l}0.026 \text { to } \\
0.077\end{array}$ & $\begin{array}{l}0.050 \text { to } \\
0.18\end{array}$ & ND & $\begin{array}{l}(0.0032) \\
\text { to } \\
(0.0036) \ddagger\end{array}$ & ND & ND \\
\hline 3 & $\begin{array}{l}\text { Agency } \\
\text { office }\end{array}$ & 4 & $\begin{array}{c}0.043 \text { to } \\
0.11\end{array}$ & $\begin{array}{c}0.062 \text { to } \\
0.17\end{array}$ & $\begin{array}{l}\text { ND to } \\
(0.0028) \ddagger\end{array}$ & ND & ND & $(0.00067) \ddagger$ \\
\hline NIOS & REL & & 250 & 1,000 & 100 & 50 & 150 & 100 \\
\hline $\mathrm{OSH}$ & EL & & 1,000 & 1,000 & 200 & 100 & 200 & 100 \\
\hline ACGI & TLV & & 500 & $1,000 \S$ & 20 & 20 & None & 100 \\
\hline \multicolumn{9}{|c|}{ REL = Recommended exposure limit } \\
\hline \multicolumn{9}{|c|}{ PEL = Permissible exposure limit } \\
\hline \multicolumn{9}{|c|}{ TLV = Threshold limit value } \\
\hline \multicolumn{9}{|c|}{$\begin{array}{l}\text { *Sampling periods ranged from } 190 \text { to } 399 \text { minutes. The work shift included the time that agents spent at the } \\
\text { raided spice lab and at their office with the collected evidence. }\end{array}$} \\
\hline \multicolumn{9}{|c|}{$\begin{array}{l}\text { †ND = not detected, below the minimum detectable concentration. For these personal samples the minimum } \\
\text { detectable concentrations for MIK ranged from } 0.002-0.01 \mathrm{ppm} \text {; for MPK } 0.0007-0.005 \mathrm{ppm} \text {; for xylene } \\
0.0006-0.005 \mathrm{ppm} \text {; for toluene } 0.001-0.008 \mathrm{ppm} \text {. }\end{array}$} \\
\hline \multicolumn{9}{|c|}{$\begin{array}{l}\text { ‡Concentration shown in parentheses is between the minimum detectable and minimum quantifiable } \\
\text { concentration (not shown). This means there is more uncertainty associated with this value. }\end{array}$} \\
\hline \multicolumn{9}{|c|}{$\begin{array}{l}\text { §A 15-minute time weighted average exposure that should not be exceeded any time during a workday } \\
\text { (a short-term exposure limit). }\end{array}$} \\
\hline
\end{tabular}

Appendix D discusses health effects of AB-PINACA and mitragynine, the psychoactive compounds that we sampled for in this evaluation. We did not find AB-PINACA or mitragynine in any of the 18 personal air samples we collected. Each agent that we collected a personal air sample for AB-PINACA and mitragynine from also provided a urine sample for these psychoactive compounds. For the personal air samples, the estimated minimum detectable concentration was 0.08 milligrams per cubic meter $\left(\mathrm{mg} / \mathrm{m}^{3}\right)$ or less for AB-PINACA and $0.06 \mathrm{mg} / \mathrm{m}^{3}$ or less for mitragynine.

We also took two area air samples for AB-PINACA and mitragynine in the spice lab, and five area samples in office areas that included the conference room, evidence storage room, and equipment room. We did not find AB-PINACA or mitragynine in any of these area air samples; estimated minimum detectable concentrations ranged from $0.03-0.1 \mathrm{mg} / \mathrm{m}^{3}$ for AB-PINACA and from $0.02-0.1 \mathrm{mg} / \mathrm{m}^{3}$ for mitragynine.

One wipe sample, taken from a baking sheet in the spice lab where treated plant material was dried, had a detectable level of AB-PINACA (Table 2). None of the other wipe samples had detectable levels of mitragynine. 
Table 2. Wipe sample results (semi-quantitative) for AB-PINACA and mitragynine

\begin{tabular}{|c|c|c|c|}
\hline Sampling date and location & Sampling method & $\begin{array}{l}\text { AB-PINACA } \\
\left(\mu \mathrm{g} / 100 \mathrm{~cm}^{2}\right)\end{array}$ & $\begin{array}{c}\text { Mitragynine } \\
\left(\mu \mathrm{g} / 100 \mathrm{~cm}^{2}\right)\end{array}$ \\
\hline \multicolumn{4}{|c|}{ 12/11/2013 - Spice lab, during raid } \\
\hline $\begin{array}{l}\text { Floor } \\
\text { Baking tray } \\
\text { Inside plastic tote } \\
\text { Inside round drum } \\
\text { Suspect liquid } † \\
\text { Equipment case }\end{array}$ & $\begin{array}{l}\text { Cotton swab } \\
\text { Cotton swab } \\
\text { Cotton swab } \\
\text { Cotton swab } \\
\text { Cotton swab } \\
\text { Cotton swab }\end{array}$ & $\begin{array}{l}\text { ND* } \\
250 \\
\text { ND } \\
\text { ND } \\
\text { ND } \\
\text { ND }\end{array}$ & $\begin{array}{l}\text { ND } \\
\text { ND } \\
\text { ND } \\
\text { ND } \\
\text { ND } \\
\text { ND }\end{array}$ \\
\hline \multicolumn{4}{|c|}{ 12/12/2013 - Agency office, before evidence processing } \\
\hline $\begin{array}{l}\text { Conference room table } \\
\text { Top of bookcase } \\
\text { Computer desk } \\
\text { Computer desk } \\
\text { Suspect bag§ } \\
\text { Suspect bag§ } \\
\text { Suspect bag§ }\end{array}$ & $\begin{array}{l}\text { Cotton swab } \\
\text { Cotton swab } \\
\text { Cotton swab } \\
\text { Macrofoam swab } \\
\text { Cotton swab } \\
\text { Macrofoam swab } \\
\text { AlphaWipe }\end{array}$ & $\begin{array}{l}\text { ND } \\
\text { ND } \\
\text { ND } \\
\text { ND } \\
\text { ND } \\
\text { ND } \\
\text { ND }\end{array}$ & $\begin{array}{l}\text { ND } \\
\text { ND } \\
\text { ND } \\
\text { ND } \\
\text { ND } \\
\text { ND } \\
\text { ND }\end{array}$ \\
\hline \multicolumn{4}{|c|}{ 12/13/2013 - Agency office, after evidence processing } \\
\hline $\begin{array}{l}\text { Conference room table } \\
\text { Conference room table } \\
\text { Conference room table } \\
\text { Computer desk }\end{array}$ & $\begin{array}{l}\text { Cotton swab } \\
\text { Macrofoam swab } \\
\text { AlphaWipe } \\
\text { AlphaWipe }\end{array}$ & $\begin{array}{l}\text { ND } \\
\text { ND } \\
\text { ND } \\
\text { ND }\end{array}$ & $\begin{array}{l}\text { ND } \\
\text { ND } \\
\text { ND } \\
\text { ND }\end{array}$ \\
\hline $\begin{array}{l}\text { Estimated limit of detection } \\
\text { Estimated limit of detection } \\
\text { Estimated limit of detection }\end{array}$ & $\begin{array}{c}\text { Cotton swab } \\
\text { AlphaWipe } \\
\text { Macrofoam swab }\end{array}$ & $\begin{array}{c}50 \\
300 \\
50\end{array}$ & $\begin{array}{c}40 \\
100 \\
40\end{array}$ \\
\hline
\end{tabular}

$\mu \mathrm{g} / 100 \mathrm{~cm}^{2}=$ micrograms per 100 square centimeter

${ }^{*} \mathrm{ND}=$ not detected, below the limit of detection.

†Wipe sample from bucket suspected to contain spice. Agents later told us that it was not spice.

$\ddagger$ Agency equipment case on the floor in the spice lab.

§Wipe samples from bags suspected to contain spice. Agents later told us that it was not spice.

\section{Workplace Observations}

Agents inconsistently used gloves and protective clothing. Their practices could expose them to contaminants and spread contamination. For example, some agents voluntarily wore disposable protective clothing (Tyvek ${ }^{\circledR}$ suits) during the raid; other agents did not. The use of latex or nitrile gloves during the raid and evidence processing was inconsistent; and no agents wore disposable shoe coverings. Some agents did not change out of the clothing (either personal or disposable) worn during the raid before entering the office. The offices did not have a designated locker room where agents could change clothing and clean up before going home.

We saw agents using the passenger elevators to bring evidence from the spice lab into the office. We watched agents sorting and processing this evidence in a carpeted conference room and individual offices, occasionally while eating and drinking. Agents could be exposed to spice or other illegal drugs through ingestion when they handle evidence with bare hands and do not wash their hands before eating, drinking, or smoking. Agents also sorted and 
processed evidence in an equipment room adjacent to the evidence storage room. This room had a tile floor and a large table with a nonporous top that could easily be cleaned. The evidence processing and storage rooms were connected to the ventilation system that supplied the remaining seventh floor offices. The potential for cross contamination in the ventilation system is discussed below.

According to agent's representatives, the agency had purchased respirators for voluntary use by the agents. These respirators included 3M model 8511 N95 filtering facepiece particulate respirators and $3 \mathrm{M}$ model 6000 series elastomeric half-mask respirators equipped with $3 \mathrm{M}$ model 6092 combination organic vapor, acid gas, and particulate cartridges. The agency contracted with Federal Occupational Health to operate the respirator program. Agents completed a questionnaire to determine if they were medically cleared to wear a respirator. Cleared agents completed fit testing for the respirator they would use. We did not see agents wearing respirators during the raid or when processing evidence. We saw some agents with facial hair that would have interfered with achieving a proper seal when wearing either of these tight-fitting respirators. The agent's repreentatives told us that the agents had not been medically cleared to wear the elastomeric half-mask respirators, only the N95 filtering facepiece respirators.

\section{Ventilation}

The agency occupied most of the seventh floor of a multitenant office building. One rooftop variable air volume air handling system provided heating and cooling for the seventh floor tenants, except for a law enforcement office in the northeast corner that was on a separate ventilation system. The ventilation system was not designed to contain or control forensic hazards from the handling and testing of evidence. Likewise, the layout of the agency's office and the work practices of the agents were not designed to contain or control hazards from receiving, processing, and storing evidence. We did not see evidence of past or present water damage, water incursion, or mold.

The ventilation system had minimum efficiency reporting value 8 panel filters. The filters were properly installed and in good condition. According to the building facility managers, the building's ventilation system normally operated from 5:00 a.m. to 6:00 p.m. on weekdays. It did not operate on the basis of occupancy nor on weekends unless outdoor temperatures were unusually cold or hot. However, agents informed us that evidence processing and other law enforcement activities did occur in the evenings and on the weekends in their offices.

We measured airflow from ceiling diffusers on the seventh floor. Although we asked, the facilities managers did not provide a design plan or a test and balance report for the ventilation system. Therefore, we were not able to compare our measured airflows to the intended design of the ventilation system. Some of the air diffusers had zero airflow, including all four diffusers in the conference room (Appendix A and Appendix B). 


\section{Questionnaire}

All nine agents participated in the questionnaire and urine monitoring. All nine were male, and the average age in years was 45 , range: $35-60$ years. The average number of years in their current job was 9, range: 4-19 years. All reported handling evidence from illegal drug raids including synthetic cannabinoids, cocaine, methamphetamine, marijuana, heroin, bath salts (slang term for synthetic cathinones), raw methylone, and prescription drugs in pill form. Cathinones and methylone are central nervous system stimulants.

All nine agents reported handling or being in the same room with the spice substance during the time of our evaluation. Two agents reported always wearing gloves, five agents reported "sometimes" or "usually" wearing gloves, and two reported not wearing gloves when handling spice during our evaluation. When asked about respirator use, six of the nine agents reported that they sometimes wore respirators during the course of their job. The types of respirators reportedly worn included dust masks (not NIOSH approved), 3M model 8511 N95 filtering facepiece respirators, and half-mask elastomeric respirators. Regarding the latter, we do not know if the agents were referring to the $3 \mathrm{M}$ model 6000 series elastomeric half-mask respirators equipped with 3M model 6092 combination organic vapor, acid gas, and particulate cartridges that had been provided for voluntary use.

We asked agents how frequently they contacted spice when working with it, even if covered by gloves or clothing. We combined responses of frequent, occasional, and rare as "yes" and reassigned responses of never to "no." Table 3 shows that the hands and forearms were the most common body parts with contact with spice.

Table 3. Number of agents reporting contact with spice, even if covered by gloves or clothing, by body part $(n=9)$

\begin{tabular}{lcc}
\hline $\begin{array}{l}\text { Part of body with } \\
\text { spice contact }\end{array}$ & $\begin{array}{c}\text { Contact with spice } \\
\text { Yes }\end{array}$ & $\begin{array}{c}\text { Contact with spice } \\
\text { No }\end{array}$ \\
\hline Hand & 9 & 0 \\
Forearm & 9 & 0 \\
Upper arm & 8 & 1 \\
Neck & 7 & 2 \\
Face & 7 & 2 \\
Leg & 5 & 4 \\
\hline
\end{tabular}


Figure 1 shows the number of agents reporting symptoms while ever handling spice. This question did not specify a time period, so symptoms could be related to historical handling of spice. Over half of the agents reported having cough, eye irritation, throat irritation, and dizziness or lightheadedness while handling spice. Four of nine agents reported feeling "high" when handling spice; three of these four agents reported irritability, difficulty remembering things, and difficulty concentrating in addition to feeling high.

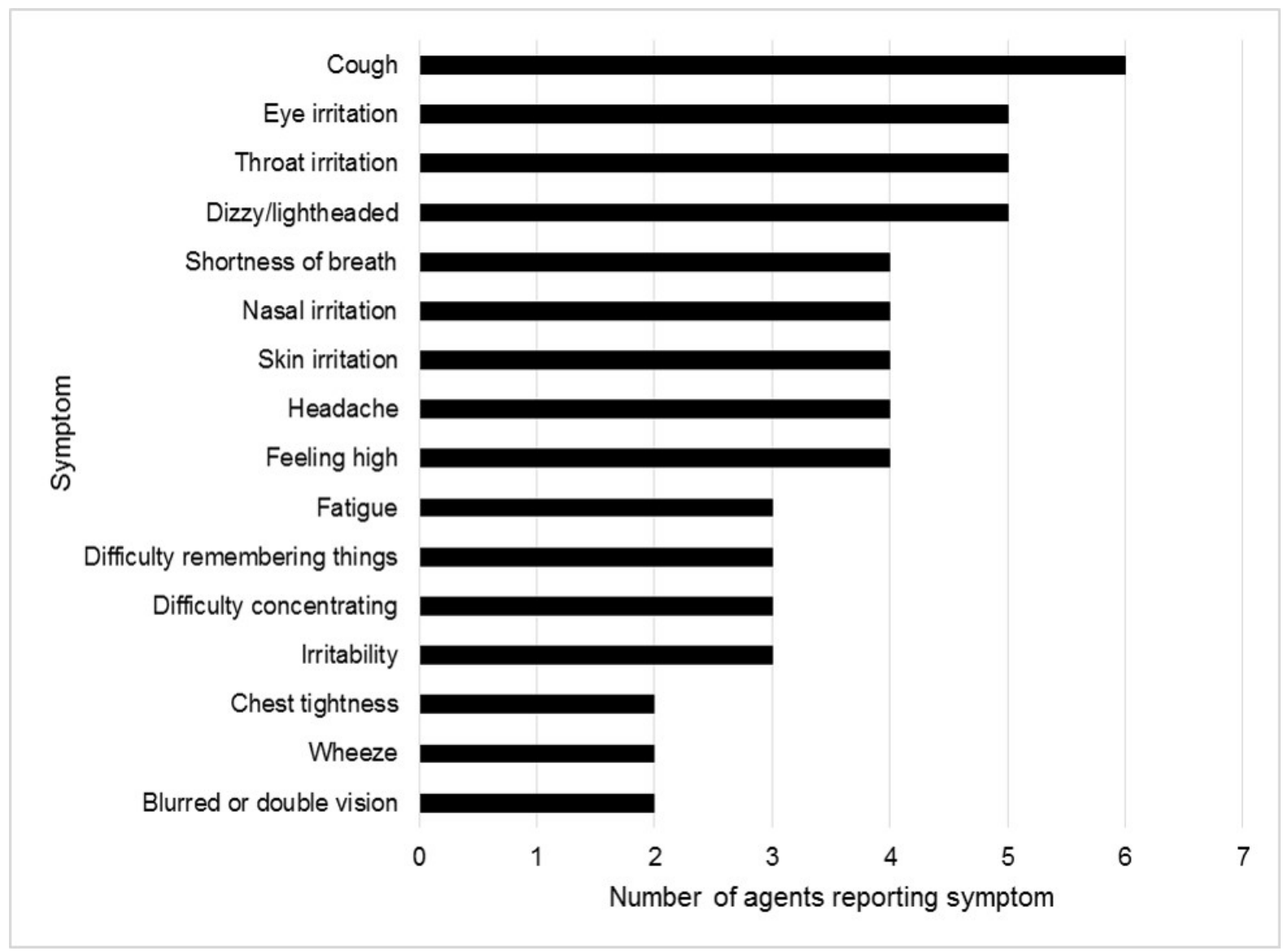

Figure 1. Number of agents reporting having symptoms while ever handling spice, by symptom type $(n=9)$.

It is possible that agents' personal habits, medical conditions, and medication use could contribute to these symptoms. Some agents reported tobacco smoking, alcohol consumption, and exposure to solvents outside of work. Some agents reported history of heart disease, high blood pressure, elevated lipids, and diabetes; and took medication for these conditions. The combined effects of taking prescription medication and being exposed to psychoactive drugs at work are unknown. We did not ask the agents about other factors, such as caffeine intake and sleep hours, that could also contribute to symptoms. 


\section{Biological Monitoring}

There are no OELs for AB-PINACA, its metabolites, or for mitragynine in urine. Since the LC-MS/MS method is considered to be more accurate than the ELISA in detecting presence of these substances, we report only the results of the LC-MS/MS analysis.

The LC-MS/MS results for AB-PINACA, its metabolites, and mitragynine in urine and the range of concentrations are shown in Table 4. On the day before the raid (day 1 baseline), no quantifiable levels of any of these compounds were found. After the raid on day 2 and day 3 , four agents had quantifiable levels of AB-PINACA and/or its metabolites in their urine samples. Two of these agents had quantifiable levels AB-PINACA N-pentanoic acid in all four urine samples on day 2 and day 3. After the raid on day 2 and 3, six employees had quantifiable levels of mitragynine in their urine. Four of these agents had quantifiable levels of mitragynine in all four urine samples on day 2 and day 3.

Table 4. Cannabinoid and mitragynine levels in agents' urine samples, by LC-MS/MS $(n=9)$

\begin{tabular}{|c|c|c|c|c|c|}
\hline \multirow[t]{2}{*}{ Compound } & \multicolumn{5}{|c|}{$\begin{array}{l}\text { Number of agents with quantifiable levels } \\
\text { (range of concentrations, } \mathrm{ng} / \mathrm{mL} \text { ) }\end{array}$} \\
\hline & $\begin{array}{l}\text { Day 1: } \\
\text { Baseline }\end{array}$ & $\begin{array}{l}\text { Day 2: } \\
\text { Post-shift }\end{array}$ & $\begin{array}{l}\text { Day 2: } \\
\text { Bedtime }\end{array}$ & $\begin{array}{l}\text { Day 3: } \\
\text { Morning }\end{array}$ & $\begin{array}{l}\text { Day 3: } \\
\text { Post-shift }\end{array}$ \\
\hline AB-PINACA* & 0 & $\begin{array}{c}3 \\
(<\mathrm{LLOQ}-0.29)\end{array}$ & $\begin{array}{c}1 \\
(<\mathrm{LLOQ}-0.12)\end{array}$ & 0 & 0 \\
\hline $\begin{array}{l}\text { AB-PINACA } \\
\text { N-(4-hydroxypentyl)* }\end{array}$ & 0 & $\begin{array}{c}1 \\
(<\mathrm{LLOQ}-0.11)\end{array}$ & $\begin{array}{c}1 \\
(<\mathrm{LLOQ}-0.12)\end{array}$ & 0 & 0 \\
\hline $\begin{array}{l}\text { AB-PINACA } \\
\text { N-pentanoic acid* }\end{array}$ & 0 & $\begin{array}{c}2 \\
(<\mathrm{LLOQ}-1.98)\end{array}$ & $\stackrel{3}{(<L L O Q-3.45)}$ & $\stackrel{2}{2}(<\mathrm{LLOQ}-0.43)$ & $\begin{array}{c}2 \\
(<L L O Q-0.62)\end{array}$ \\
\hline Mitragynine & 0 & $\begin{array}{c}4 \\
(<\text { LLOQ-3.70) }\end{array}$ & $\begin{array}{c}5 \\
(<\text { LLOQ-12.62) }\end{array}$ & $\begin{array}{c}5 \\
(<\mathrm{LLOQ}-0.94)\end{array}$ & $\begin{array}{c}5 \\
(<L L O Q-5.28)\end{array}$ \\
\hline \multicolumn{6}{|c|}{ LLOQ = lower limit of quantification } \\
\hline \multicolumn{6}{|c|}{$\begin{array}{l}\text { *The LLOQ for AB-PINACA, AB-PINACA N-(4-hydroxypentyl) metabolite and AB-PINACA N-pentanoic } \\
\text { acid metabolite is } 0.10 \mathrm{ng} / \mathrm{mL} \text {. }\end{array}$} \\
\hline \multicolumn{6}{|c|}{ †The LLOQ for mitragynine is $1.0 \mathrm{ng} / \mathrm{mL}$. } \\
\hline
\end{tabular}

The agent with the greatest number of positive urine samples and highest concentrations reported not wearing gloves during the evaluation. We observed that this agent also handled most of the evidence. In contrast, three agents had no quantifiable levels for any of the four analytes. Two of those agents did not handle evidence during the raid or participate in evidence processing; the third agent participated in both activities and reported some glove use. The remaining five agents handled evidence during the raid and reported varied glove use from none to always. One of these five agents was a smoker, reported usually wearing gloves, and thus may have had hand-to-mouth exposure. 


\section{Discussion}

\section{Synthetic Cannabinoids and Mitragynine}

We found detectable levels of AB-PINACA, its metabolites, or mitragynine in six of nine agents after the raid. One of the surface wipe samples from the spice lab and none of the agents' personal air samples contained detectable levels of AB-PINACA or mitragynine. The sampling and analytical methods we used to test for these psychoactive compounds have not been validated. Appendix $\mathrm{C}$ discusses method limitations, particularly low recoveries and extraction efficiencies.

The urine results suggest that workplace exposures to AB-PINACA and mitragynine occurred during the raid or evidence processing and that agents absorbed these chemicals into their bodies. Agents handling evidence without gloves and while eating and drinking risk ingesting the chemicals or absorbing them through the skin.

Little information is available in the scientific literature about exposures to synthetic cannabinoids and mitragynine and human health effects. We do not know the concentrations of synthetic cannabinoids and mitragynine in urine that would be expected from airborne, dermal, or ingestion exposures nor the levels at which symptoms or health effects would be expected. We did not find reports in the scientific literature describing occupational exposure to synthetic cannabinoids such as AB-PINACA and to mitragynine. However, the levels found among agents in this evaluation are much lower than the levels found in patients presenting to the emergency department after intentional use [Gerona 2015].

\section{Volatile Organic Compounds}

The concentrations of the six measureable VOCs in the personal air samples were well below their lowest OELs. One of these six was ethanol, the suspected solvent used to dissolve the synthetic drugs. Volatile organic compounds are a large class of organic chemicals (containing carbon) that have a sufficiently high vapor pressure to allow some of the compound to exist in the gaseous state at room temperature. These compounds are emitted in varying concentrations from many common indoor sources, including carpeting, fabrics, adhesives, solvents, paints, cleaners, waxes, cigarettes, and combustion sources.

\section{Ventilation}

A variable air volume air handling system like the one present in the agency's office should provide minimum airflow at all times to avoid stagnant air conditions developing in occupied spaces. However, we measured no airflow from the supply diffusers in the conference room. The ventilation system at the agency's office was not designed to contain or control forensic hazards from the handling and storage of evidence. Likewise, the layout of the agency's office and the work practices of the agents did not contain or control potential hazards from the receiving, processing, and storing of evidence. At the time of our evaluation, a new office was planned, although the completion date was not known, and no design plans were available to review. 
In addition to a properly designed forensic facility, good hygiene practices by the agents, such as washing hands before eating, drinking, smoking, and using personal protective equipment, will also reduce personal exposures to potential contaminants during raids and while handling evidence.

\section{Personal Protective Equipment}

Selecting the appropriate type of personal protective equipment can be challenging in this situation because of the expected variability between raids. For example, raided facilities can differ in the size of the lab, the types and quantities of drugs, and the presence or absence of exterior doors, windows, and mechanical ventilation systems. These differences will affect agents' exposures. For these reasons, managers should consider information they receive before a raid in deciding about the need for and level of personal protective equipment, including respiratory protection. We do not have sufficient information based on this evaluation to make a general recommendation on an appropriate level of respiratory protection for all raids. However, regardless of the field situation, a minimum level of personal protective equipment, such as disposable clothing and protective gloves, should be required while working in clandestine drug labs. A properly designed forensic facility where potentially contaminated evidence can be safely transferred, processed, and stored will further help to minimize unnecessary exposures to illicit drugs, VOCs, and other contaminants.

\section{Limitations}

Our evaluation had the following limitations:

- We observed only one spice lab raid that involved a small number of agents. The findings may not represent other raids.

- Agents may have been exposed to psychoactive compounds during the raid that were unknown to us.

- The air and surface wipe sampling and analytical methods we used for AB-PINACA and mitragynine have not been validated; therefore our results should be considered semi-quantitative.

- The analytical tests run on the urine specimens are new and investigational.

- We could not compare agents' symptoms with urine levels of cannabinoids and mitragynine. We asked about symptoms in general when handling spice, not symptoms specifically during the evaluation.

\section{Conclusions}

Our findings indicate that agents are at risk for dermal and ingestion exposures, and have the potential for unnecessary airborne exposures to synthetic cannabinoids and other contaminants. The risk arises from collecting and processing contaminated evidence and occurs in the field and office. A minimum level of personal protective equipment, such as disposable clothing and protective gloves, should be required. A hazard assessment 
should be used to determine if agents also need additional personal protective equipment such as respirators. This assessment should use information about the lab to be raided and from previous raids. A properly designed forensic facility will further help to minimize unnecessary exposures to illicit drugs, VOCs, and other contaminants.

\section{Recommendations}

On the basis of our findings, we recommend the actions listed below. We encourage the law enforcement agency to use a labor-management health and safety committee or working group to discuss our recommendations and develop an action plan. Those involved in the work can best set priorities and assess the feasibility of our recommendations for the specific situation at the agency.

Our recommendations are based on an approach known as the hierarchy of controls (Appendix D). This approach groups actions by their likely effectiveness in reducing or removing hazards. In most cases, the preferred approach is to eliminate hazardous materials or processes and install engineering controls to reduce exposure or shield employees. Until such controls are in place, or if they are not effective or feasible, administrative measures and personal protective equipment may be needed.

\section{Engineering Controls}

Engineering controls reduce employees' exposures by removing the hazard from the process or by placing a barrier between the hazard and the employee. Engineering controls protect employees effectively without placing primary responsibility of implementation on the employee.

1. Design an office to accommodate a variety of purposes such as general offices; laboratories; evidence receiving, processing, and storage areas. To this end, review the new building plans to determine if the following goals are addressed.

a. Designing the ventilation system(s) to contain potential contaminants from processing and storing evidence.

b. Designating routes within the building for transporting evidence from the field to storage and processing locations to minimize the spread of contaminants to surrounding office areas.

c. Providing areas or rooms specifically designed to hold evidence and for handling and processing evidence.

d. Using easy-to-clean, nonporous surfaces.

e. Providing a locker and shower area for employees to use to reduce contamination within the facility as well as prevent take-home exposure.

The following links provide information on forensic facility design, including a modular planning concept that allows flexibility in accommodating the differing needs of office, lab, and storage areas.

a. Forensic Facility Design, Part 1 (http://www.forensicmag.com/ articles/2005/04/forensic-facility-design).

b. Forensic Facility Design, Part 2 (http://www.forensicmag.com/ articles/2005/01/design-forensic-facilities-part-2). 
2. Store and process evidence in the office space in the northeast corner of the seventh floor because this area has its own ventilation system. Doing so will reduce the chance of recirculating potentially contaminated air to other occupied spaces on the seventh floor.

3. Evaluate the ventilation system serving the seventh floor. All of the variable air volume supply boxes should provide a minimum amount of air during occupancy to avoid stagnant air conditions. After making repairs, perform a test and balance of the ventilation system.

\section{Administrative Controls}

The term administrative controls refers to employer-dictated work practices and policies to reduce or prevent hazardous exposures. Their effectiveness depends on employer commitment and employee acceptance. Regular monitoring and reinforcement are necessary to ensure that policies and procedures are followed consistently.

1. Train employees on proper work practices and hygiene when working with potentially hazardous substances. Prohibit eating and drinking in areas where evidence is processed. Improve personal hygiene practices such as hand washing after handling potentially contaminated items, after glove removal, and before eating and drinking.

2. Provide hand-washing supplies, soap, and water, for agents to use in the field.

3. Train employees in proper donning and doffing techniques of personal protective equipment to avoid skin contamination. Training should also include the reasons for the protective equipment use and its limitations.

4. Do not sort or process evidence outside of the equipment storage room.

5. Avoid working in the office between 6:00 p.m. and 5:00 a.m. or other times when the building's ventilation system is not operating. If work is necessary during these times consult with the building's facilities managers to adjust the operating schedule of the ventilation system.

6. Encourage agents to report potential work-related health conditions to their supervisor. Agents with persistent symptoms should be evaluated by an occupational medicine physician or a medical provider specializing in workplace diseases and illnesses. The Association of Occupational and Environmental Clinics has an online directory of such providers at http://www.aoec.org/directory.htm.

7. Evaluate potential hazards in future raids to help inform decisions regarding a minimum level of personal protective equipment for agents entering clandestine spice labs. This information could then be included in a written standard operating procedure for selecting the appropriate level of personal protective equipment.

8. Conduct a hazard assessment prior to each raid to decide what personal protective equipment, including respiratory protection, may be needed. 


\section{Personal Protective Equipment}

Personal protective equipment is the least effective means for controlling hazardous exposures. Proper use of personal protective equipment requires a comprehensive program and a high level of employee involvement and commitment. The right personal protective equipment must be chosen for each hazard. Supporting programs such as training, changeout schedules, and medical assessment may be needed. Personal protective equipment should not be the sole method for controlling hazardous exposures. Rather, personal protective equipment should be used until effective engineering and administrative controls are in place.

1. Wear disposable protective gloves when handling items that may be contaminated. Do not use latex gloves for activities that are not likely to involve contact with infectious materials because of potential allergic reactions. Many types of glove materials are available, such as nitrile, polyvinyl chloride, neoprene, and polyvinyl alcohol. Each glove material provides different levels of protection from chemicals and liquids, and varying levels of cut, tear, abrasion, puncture, and thermal resistance. We recommend using the information gained from hazard assessments to help select the most appropriate glove material for each event and type of work. Nitrile gloves like the ones worn by agents in this evaluation provide good protection from ethanol and isopropanol (also called isopropyl alcohol or "rubbing alcohol") [Ansell 2015]. In this evaluation, ethanol was the most prevalent VOC present in the air samples we collected.

2. Provide disposable protective clothing, including shoe covers, for all agents working in potentially contaminated areas and when collecting and processing evidence. Like protective gloves, protective clothing materials provide varying levels of protection to particulates and chemicals as well as to fabric cuts and tears. The breathable Tyvek disposable suits worn by the agents in this evaluation provide barrier protection against small size hazardous particles [DuPont 2016]. Although not as breathable as Tyvek, disposable TyChem ${ }^{\circledR}$ protective suits provide the wearer with chemical protection against many toxic liquids and vapors [DuPont 2016]. We recommend using the information from hazard assessments to help select the most appropriate clothing material for each event and type of work.

3. Make sure agents are medically cleared by Federal Occupational Health for each respirator that they may voluntarily use. For voluntary use, agents must be provided with Appendix D from the OSHA respiratory protection standard 1910.134 (Information for Employees Using Respirators When not Required Under Standard). Additionally, agents must be medically evaluated for voluntary use of any respirator, except for voluntary use of disposable filtering facepiece respirators. Agents should also be informed that facial hair can interfere in the facepiece to face seal, and supervisors should monitor the proper use and wearing of respirators by agents to include the presence of facial hair. If respirators are required in the future, ensure that the respiratory protection program meets all required elements in the OSHA respiratory protection standard. 


\section{Appendix A: Tables}

Table A1. Air supply measurements, seventh floor

\begin{tabular}{|c|c|c|c|c|c|}
\hline \multirow{3}{*}{$\begin{array}{l}\text { Diffuser } \\
\text { (Figure B1) }\end{array}$} & \multicolumn{4}{|c|}{ Airflow, cubic feet per minute } & \multirow[t]{3}{*}{ Comments } \\
\hline & \multicolumn{3}{|c|}{ Measurement } & \multirow[t]{2}{*}{ Average } & \\
\hline & 1 & 2 & 3 & & \\
\hline A & 33 & 34 & 32 & 33 & \\
\hline B & 22 & 26 & 29 & 26 & \\
\hline C & 33 & 32 & 32 & 32 & \\
\hline $\mathrm{D}$ & 51 & 51 & 51 & 51 & \\
\hline E & 30 & 29 & 31 & 30 & \\
\hline $\mathrm{F}$ & 20 & 20 & 20 & 20 & \\
\hline G & 25 & 24 & 28 & 26 & \\
\hline $\mathrm{H}$ & 62 & 61 & 61 & 61 & \\
\hline 1 & 35 & 36 & 38 & 37 & \\
\hline $\mathrm{J}$ & 0 & 0 & 0 & 0 & \\
\hline K & 84 & 88 & 86 & 86 & \\
\hline L & 79 & 79 & 79 & 79 & \\
\hline M & 117 & 121 & 122 & 120 & \\
\hline N & 64 & 64 & 65 & 64 & $\begin{array}{c}\text { Corner column area not shown on } \\
\text { diagram shown }\end{array}$ \\
\hline O & 20 & 0 & 0 & 7 & $\begin{array}{c}\text { Corner column area not shown on } \\
\text { diagram shown }\end{array}$ \\
\hline$P$ & 161 & 160 & 161 & 161 & \\
\hline Q & 175 & 174 & 174 & 174 & \\
\hline $\mathrm{R}$ & 84 & 85 & 86 & 85 & \\
\hline$S$ & 83 & 82 & 86 & 84 & \\
\hline $\mathrm{T}$ & 75 & 74 & 71 & 73 & $\begin{array}{c}\text { Corner column area not shown on } \\
\text { diagram shown }\end{array}$ \\
\hline$u$ & 40 & 37 & 38 & 38 & $\begin{array}{c}\text { Corner column area not shown on } \\
\text { diagram shown }\end{array}$ \\
\hline v & 100 & 101 & 99 & 100 & Average of two adjacent diffusers \\
\hline W & 174 & 180 & 179 & 178 & \\
\hline$x$ & 194 & 189 & 190 & 191 & \\
\hline Y & 35 & 33 & 31 & 33 & \\
\hline Z & 35 & 37 & 35 & 36 & \\
\hline
\end{tabular}

All ceiling diffusers were 2 feet by 2 feet 
Table A2. Airflow measurements, seventh floor

\begin{tabular}{|c|c|c|c|c|c|}
\hline \multirow{3}{*}{$\begin{array}{l}\text { Diffuser } \\
\text { (Figure B1) }\end{array}$} & \multicolumn{4}{|c|}{ Airflow, cubic feet per minute } & \multirow[t]{3}{*}{ Comments } \\
\hline & \multicolumn{3}{|c|}{ Measurement } & \multirow[t]{2}{*}{ Average } & \\
\hline & 1 & 2 & 3 & & \\
\hline$A A$ & 51 & 52 & 55 & 53 & \\
\hline BB & 67 & 67 & 69 & 68 & \\
\hline $\mathrm{CC}$ & & & & & $\begin{array}{c}\text { No measurements, } \\
\text { office locked }\end{array}$ \\
\hline DD & & & & & $\begin{array}{c}\text { No measurements, } \\
\text { office locked }\end{array}$ \\
\hline EE & 39 & 40 & 41 & 40 & \\
\hline FF & 38 & 37 & 39 & 38 & \\
\hline GG & 105 & 105 & 105 & 105 & \\
\hline $\mathrm{HH}$ & 97 & 96 & 96 & 96 & \\
\hline II & 0 & 0 & 0 & 0 & \\
\hline $\mathrm{JJ}$ & 0 & 0 & 0 & 0 & \\
\hline KK & 0 & 0 & 0 & 0 & \\
\hline LL & 0 & 0 & 0 & 0 & \\
\hline MM & 180 & 182 & 183 & 182 & \\
\hline NN & 250 & 251 & 244 & 248 & \\
\hline OO & 0 & 0 & 0 & 0 & \\
\hline PP & 0 & 0 & 0 & 0 & \\
\hline$Q Q$ & 35 & 34 & 34 & 34 & \\
\hline $\mathrm{RR}$ & 129 & 130 & 128 & 129 & \\
\hline SS & 75 & 75 & 76 & 75 & \\
\hline TT & 71 & 72 & 72 & 72 & \\
\hline UU & 94 & 93 & 93 & 93 & \\
\hline VV & 94 & 96 & 95 & 95 & \\
\hline WW & 31 & 34 & 33 & 33 & \\
\hline
\end{tabular}

All ceiling diffusers were 2 feet by 2 feet 


\section{Appendix B: Figure}

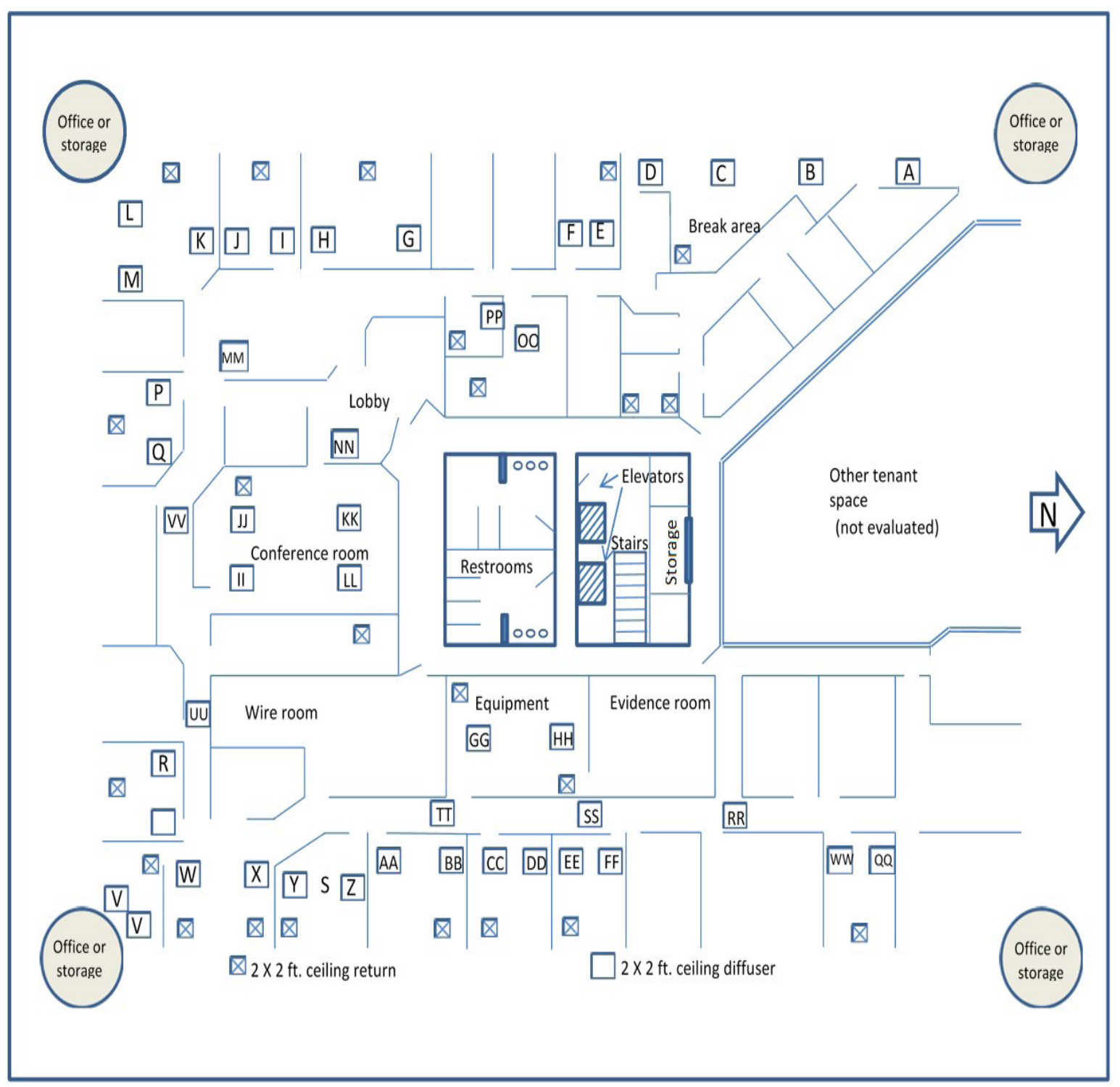

Figure B1. Office diffuser locations, seventh floor 


\section{Appendix C: Methods}

\section{Enzyme Linked Immuno-sorbent Assay}

ELISA assays are often used as screening methods but may have a limitation of reacting to structurally similar compounds. In this evaluation we used the AB-PINACA assay from Randox Toxicology Limited, United Kingdom to screen for AB-PINACA in urine. This is a competitive ELISA, meaning that AB-PINACA in the sample competes with enzymelabelled AB-PINACA for a limited number of anti-AB-PINACA binding sites in test wells coated with AB-PINACA antibody. The more AB-PINACA present in the samples, the fewer enzyme labelled AB-PINACA - antibody complexes are present that are responsible for the color development in the assay. Therefore, more AB-PINACA in the sample means less color. The same laboratory also developed an ELISA assay to screen for mitragynine in urine.

\section{Liquid Chromatography Tandem Mass Spectroscopy Test}

Because ELISA is a screening test that can have interferences, we used an LC-MS/MS method developed by researchers at the University of California San Francisco to confirm the presence of AB-PINACA, AB-PINACA N-(4-hydroxypentyl) metabolite, AB-PINACA $\mathrm{N}$-pentanoic acid metabolite, and mitragynine in the urine samples. Using Agilent LC 1260- AB Sciex 5500, all four compounds were measured using electrospray ionization in the positive polarity. Each analyte was monitored by multiple reaction monitoring using two transitions. Labeled paroxetine, an antidepressant drug, was used as an internal standard.

Each urine sample $(0.5$ milliliter $[\mathrm{mL}])$ was thawed and centrifuged at 3,000 rotations per minute for 10 minutes before it was prepared for LC-MS/MS analysis by deconjugation using $\mathrm{H}$. pomatia beta-glucuronidase and $\mathrm{H}$. pomatia sulfatase. Twenty-five microliters of a five-fold diluted deconjugated urine aliquot of the extract was used for each of the replicate injections of the sample. Chromatography was done in an Agilent Poroshell 120 column $(2.1 \times 100$ millimeter, $2.7 \mu \mathrm{m})$ maintained at $50^{\circ} \mathrm{C}$ and at a flow rate of 0.6 milliliters per minute. Chromatographic separation of the analytes was achieved by gradient elution using water with $0.05 \%$ formic acid and 5 millimole ammonium formate as mobile phase $\mathrm{A}$ and acetonitrile with $0.05 \%$ formic acid as mobile phase B. A millimole is a standard scientific unit for measuring large quantities of very small entities such as atoms, molecules, or other specified particles. The elution gradient employed was $0-0.5$ minutes $=5 \% \mathrm{~B} ; 2.5$ minutes $=$ $100 \% \mathrm{~B} ; 2.5-4.5$ minutes $=100 \% \mathrm{~B} ; 4.6$ minutes $=5 \% \mathrm{~B}$ and $4.6-6.5$ minutes $=5 \% \mathrm{~B}$. Two quality control materials were used at low $(1 \mathrm{ng} / \mathrm{mL})$ and high $(20 \mathrm{ng} / \mathrm{mL})$ concentrations. To accept the results of a batch run, quality control materials measurements were set to be within $20 \%$ of their target values.

The LC-MS/MS LLOQ for AB-PINACA, AB-PINACA N-(4-hydroxypentyl) metabolite, and AB-PINACA N-pentanoic acid metabolite was $0.10 \mathrm{ng} / \mathrm{mL}$, and the LLOQ for mitragynine was $1.0 \mathrm{ng} / \mathrm{mL}$. Quantitation of each analyte was done by isotope dilution method using a 10-point calibration curve. Data analysis was done using AB-Sciex MultiQuant software. 


\section{Air and Surface Wipe Sampling for AB-PINACA and Mitragynine}

We do not have validated sampling and analytical methods for either of these psychoactive compounds, so the results from these analyses should be considered semi-quantitative. The limits of detection and quantitation are estimates and provided for advisory purposes.

For the air samples we selected 37-millimeter diameter, 2-micrometer pore size polytetrafluoroethylene filters. Following sample collection, each filter was transferred to a $4 \mathrm{~mL}$ vial, then extracted with $2 \mathrm{~mL}$ of methanol. We used a similar sample extraction approach for the three surface wipe sample media that we used in this evaluation. For the cotton AlphaWipes the sample media was transferred to a $50 \mathrm{~mL}$ Falcon tube and extracted with $20 \mathrm{~mL}$ of methanol. For the Puritan cotton swabs the media was extracted with $1.5 \mathrm{~mL}$ of methanol, and for the macrofoam swabs the media were transferred to a $4 \mathrm{~mL}$ vial, then extracted with $2 \mathrm{~mL}$ of methanol. Following extraction the samples were shaken for 30 minutes.

For all the samples an extract was obtained by transferring a $0.1 \mathrm{~mL}$ aliquot of the extraction solvent to an auto-sampler insert. Two 2.0 microliters of a 2,000 micrograms per milliliter internal standard that consisted of phenanthrene-d10 was added. The mixture was briefly mixed on a vortex and then analyzed using gas chromatography/mass spectroscopy using the following parameters.

\section{Analytical Run Parameters:}

Instrument: $\quad$ Hewlett Packard Model 6890 Gas Chromatograph/Hewlett Packard Model 5972 Mass Selective Dectector

Column: $\quad$ Phenomenex ${ }^{\circledR} \mathrm{ZB}-5 \mathrm{MS}, 30$ meter, 0.25 -millimeter interior diameter with a 0.25 micrometer film thickness

Column Flow: $\quad$ Pressure program, approximately 1.5 milliliter per minute

Injection Temperature: $280^{\circ} \mathrm{C}$

Injection Volume: 1 microliter

Oven Temperature Profile:

Initial Temperature: $50^{\circ} \mathrm{C}$

Initial Hold Time: 10 minutes

Temp. Program Rate: $20^{\circ} \mathrm{C} /$ minute

Temperature: $\quad 90^{\circ} \mathrm{C}$

Hold Time: $\quad 0.5$ minutes

Temp. Program Rate: $12^{\circ} \mathrm{C} /$ minute

Temperature: $\quad 290^{\circ} \mathrm{C}$

Hold Time: $\quad 0.5$ minutes

Temp. Program Rate: $20^{\circ} \mathrm{C} /$ minute

Final Temperature: $\quad 320^{\circ} \mathrm{C}$

Final Hold Time: $\quad 3.0$ minutes

Mass Spectrometer Operating Parameters:

SCAN mode: $\quad 35-500$ atomic mass units 
Tables C1 and C2 summarize the estimated limits of detection and quantitation obtained by spiking media supplied by our analytical laboratory.

Table C1. Estimated limits of detection and quantitation for air filter samples and macrofoam and cotton swab wipe samples, in micrograms per sample

\begin{tabular}{lccc}
\hline Compound & Limit of detection & Limit of quantitation & Analytical range \\
\hline AB-PINACA & 50 & $240^{*}$ & $50-500$ \\
Mitragynine & 40 & $150^{*}$ & $40-500$ \\
\hline
\end{tabular}

* Limit of quantitation raised to the $75 \%$ recovery of the laboratory control sample.

Table C2. Estimated limits of detection and quantitation for cotton AlphaWipe samples, in micrograms per sample

\begin{tabular}{lccc}
\hline Compound & Limit of detection & Limit of quantitation & Analytical range \\
\hline AB-PINACA & 300 & Not achieved $^{*}$ & $300-5000$ \\
Mitragynine & 100 & Not achieved $^{*}$ & $100-5000$ \\
\hline
\end{tabular}

${ }^{*} 75 \%$ recovery of the laboratory control sample was not achieved.

We also looked at the extraction efficiency of methanol for the different media types and performed other quality control tests. A recovery study was performed on the various media at two levels, spiked in triplicate. On the basis of our limited study and other quality control parameters, it appears that methanol may not be the best media/extraction solvent combination. 


\section{Appendix D: Occupational Exposure Limits and Health Effects}

NIOSH investigators refer to mandatory (legally enforceable) and recommended OELs for chemical, physical, and biological agents when evaluating workplace hazards. OELs have been developed by federal agencies and safety and health organizations to prevent adverse health effects from workplace exposures. Generally, OELs suggest levels of exposure that most employees may be exposed to for up to 10 hours per day, 40 hours per week, for a working lifetime, without experiencing adverse health effects. However, not all employees will be protected if their exposures are maintained below these levels. Some may have adverse health effects because of individual susceptibility, a pre-existing medical condition, or a hypersensitivity (allergy). In addition, some hazardous substances act in combination with other exposures, with the general environment, or with medications or personal habits of the employee to produce adverse health effects. Most OELs address airborne exposures, but some substances can be absorbed directly through the skin and mucous membranes.

Most OELs are expressed as a time-weighted average (TWA) exposure. A TWA refers to the average exposure during a normal 8- to 10-hour workday. Some chemical substances and physical agents have recommended short-term exposure limits or ceiling values. Unless otherwise noted, the short-term exposure limit is a 15-minute TWA exposure. It should not be exceeded at any time during a workday. The ceiling limit should not be exceeded at any time.

In the United States, OELs have been established by federal agencies, professional organizations, state and local governments, and other entities. Some OELs are legally enforceable limits; others are recommendations.

- The U.S. Department of Labor OSHA PELs (29 CFR 1910 [general industry]; 29 CFR 1926 [construction industry]; and 29 CFR 1917 [maritime industry]) are legal limits. These limits are enforceable in workplaces covered under the Occupational Safety and Health Act of 1970.

- NIOSH RELs are recommendations based on a critical review of the scientific and technical information and the adequacy of methods to identify and control the hazard. NIOSH RELs are published in the NIOSH Pocket Guide to Chemical Hazards [NIOSH 2010]. NIOSH also recommends risk management practices (e.g., engineering controls, safe work practices, employee education/training, personal protective equipment, and exposure and medical monitoring) to minimize the risk of exposure and adverse health effects.

- Other OELs used and cited in the United States include the TLVs, which are recommended by ACGIH, a professional organization, and the workplace environmental exposure levels, which are recommended by the American Industrial Hygiene Association, another professional organization. The TLVs and workplace environmental exposure level are developed by committee members of these associations from a review of the published, peer-reviewed literature. These OELs are not consensus standards. TLVs are considered voluntary exposure guidelines for use by industrial hygienists and others trained in this discipline "to assist in the control of 
health hazards" [ACGIH 2015]. Workplace environmental exposure levels have been established for some chemicals "when no other legal or authoritative limits exist" [AIHA 2015].

Outside the United States, OELs have been established by various agencies and organizations and include legal and recommended limits. The Institut für Arbeitsschutz der Deutschen Gesetzlichen Unfallversicherung (Institute for Occupational Safety and Health of the German Social Accident Insurance) maintains a database of international OELs from European Union member states, Canada (Québec), Japan, Switzerland, and the United States. The database, available at http://www.dguv.de/ifa/GESTIS/GESTIS-Stoffdatenbank/index-2.jsp, contains international limits for more than 1,500 hazardous substances and is updated periodically.

OSHA requires an employer to furnish employees a place of employment free from recognized hazards that cause or are likely to cause death or serious physical harm [Occupational Safety and Health Act of 1970 (Public Law 91-596, sec. 5(a)(1))]. This is true in the absence of a specific OEL. It also is important to keep in mind that OELs may not reflect current health-based information.

When multiple OELs exist for a substance or agent, NIOSH investigators generally encourage employers to use the lowest OEL when making risk assessment and risk management decisions. NIOSH investigators also encourage use of the hierarchy of controls approach to eliminate or minimize workplace hazards. This includes, in order of preference, the use of (1) substitution or elimination of the hazardous agent, (2) engineering controls (e.g., local exhaust ventilation, process enclosure, dilution ventilation), (3) administrative controls (e.g., limiting time of exposure, employee training, work practice changes, medical surveillance), and (4) personal protective equipment (e.g., respiratory protection, gloves, eye protection, hearing protection). Control banding, a qualitative risk assessment and risk management tool, is a complementary approach to protecting employee health. Control banding focuses on how broad categories of risk should be managed. Information on control banding is available at http://www.cdc.gov/niosh/topics/ctrlbanding/. This approach can be applied in situations where OELs have not been established or can be used to supplement existing OELs.

\section{Psychoactive Compounds}

\section{Synthetic Cannabinoids}

In the 1960s, the pharmaceutical community developed synthetic cannabinoids like AB-PINACA while trying to find a product with the analgesic and anti-inflammatory properties of tetrahydrocannabinol in marijuana without psychotropic side effects [Rosenbaum et al. 2012]. Recently, synthetic cannabinoids, also known as spice, have become designer drugs of abuse because of their psychoactive properties. Synthetic cannabinoids first appeared in the United States in 2008, and by 2011, the DEA had given several synthetic cannabinoids schedule I status, making it illegal to manufacture, distribute, dispense, or possess the controlled substance [DEA 2011]. To avert the illegal status, spice packages are commonly marked as "incense" or "not for human consumption." 
Synthetic cannabinoids have similar effects as the psychoactive compound, $\Delta$-9-tetrahydrocannabinol, found in marijuana. However, synthetic cannabinoids are high-potency full agonists at the cannabinoid brain receptor, unlike tetrahydrocannabinol, which is a low-potency partial agonist [Spaderna et al. 2013]. An agonist is a substance that acts like another substance and therefore stimulates an action. Symptoms of toxicity from synthetic cannabinoid use vary by route of exposure, type of synthetic cannabinoid, and dose. Reported symptoms of abuse include anxiety, agitation, paranoia, hallucinations, seizures, tachycardia, hypertension, excessive sweating, nausea, and vomiting [Hermanns-Clausen et al. 2012; Seely et al. 2012; Harris and Brown 2013; Spaderna et al. 2013]. Other negative health effects associated with the use of synthetic cannabinoids include respiratory depression needing intubation [Jinwala and Gupta 2012], psychiatric complications resulting in suicide [Patton et al. 2013], acute kidney injury [CDC 2013; Buser et al. 2014], hyperthermia and rhabdomyolysis [Hermanns-Clausen et al. 2012], acute myocardial infarction [Mir et al. 2011; Streich et al. 2014], and acute cerebral ischemia [Takematsu et al. 2014]. Synthetic cannabinoids are not currently identified by routine screening tests.

\section{Mitragynine}

Mitragynine, derived from the Mitragyna speciose plant in subtropical regions of Asia, is used by drug users when opium is unavailable [Hanapi et al. 2013]. Mitragyna speciose preparations have been used by Malay and Thai natives for their opium and coca-like effects to enhance tolerance for hard work under the hot sun [Grewal 1932a,b; Suwanlert 1975; Tanguay 2011]. Studies have found this drug to have similar analgesic and antitussive properties as codeine [Matsumoto et al. 1996].

In Western societies, Mitragyna speciose preparations are accessible from local coffee shops and web-based "legal highs" pharmacies [Boyer et al. 2008; Hillebrand et al. 2010]. This has enticed many consumers to self-treat with mitragynine to modulate opiate withdrawal, alcohol withdrawal, and chronic pain [Boyer et al. 2008; Havemann-Reinecke 2011; Ward et al. 2011]. It is also a cheaper alternative to established opioid-replacement therapies and is obtainable without medical prescription.

There is a general effect of "cocaine-like" stimulation in small doses, while at high doses "morphine-like" sedation and nausea are reported [Babu et al. 2008]. Several publications suggest that Mitragyna speciose preparations have analgesic, antipyretic, antidiarrheal, euphoric, anti-depressant, and anxiolytic effects [ASEAN 2010]. They may work as immune booster, lower blood pressure, and have antiviral, diabetes-suppressing, and appetitesuppressing effects [Burkill 1935; Macko et al. 1972]. Besides this, they can also cause anorexia, dry mouth, diuresis and constipation after long-term use at high doses [Suwanlert 1975]. While there was no evidence of a dosage increment among long-term and repeated users, withdrawal symptoms were reported, which suggests an addiction potential. These symptoms range from hostility, aggression, aching of muscles and bones, jerky movements of the limbs, and anorexia to weight loss and insomnia [Suwanlert 1975].

In Indonesia, kratom is legally cultivated and exported on large scale to Asia, North America, and Europe [Tanguay 2011]. Mitragyna speciose and/or mitragynine and 7-HMG 
are controlled drugs in many European Union countries including Denmark, Poland, and Sweden. In other countries they are under the control of the narcotic laws, including Australia and Myanmar. In the United States, the United Kingdom, and Germany they are currently not controlled substances but under surveillance [EMCDDA 2015]. The DEA has placed kratom on its Drugs and Chemicals of Concern list, which suggests that the agency may eventually try to ban it in the United States once more reliable data on its addictive properties and/or health hazards become available [DEA 2011].

\section{Acetone and Ethanol}

Acetone is a widely used industrial solvent that can be irritating to the eyes and mucous membranes and at concentrations much higher than those we measured in this evaluation may depress the central nervous system [Hathaway and Proctor 2004]. Acetone can also be absorbed through the skin [Hathaway and Proctor 2004]. Ethanol, also called ethyl alcohol, can have health effects similar to acetone, but at concentrations higher than those measured here [Hathaway and Proctor 2004]. Unlike acetone, ethanol is not appreciably irritating to skin [Hathaway and Proctor 2004]. Occupational exposure limits for acetone and ethanol are in Table 1. 


\section{References}

ACGIH [2015]. 2015 TLVs ${ }^{\circledR}$ and BEIs ${ }^{\circledR}$ : threshold limit values for chemical substances and physical agents and biological exposure indices. Cincinnati, OH: American Conference of Governmental Industrial Hygienists.

AIHA (American Industrial Hygiene Association) [2015]. AIHA 2015 Emergency response planning guidelines (ERPG) \& workplace environmental exposure levels (WEEL) handbook. Fairfax, VA: American Industrial Hygiene Association.

Ansell [2015]. Ansell chemical protective gloves guide. [http:/www.ppe.ansell.com.au/ chemical-glove-guide]. Date accessed: March 2016.

ASEAN [2010]. ASEAN herbal and medicinal plants. Compiled by contributors to The Association of Southeast Asian Nations (ASEAN), Jakarta: ASEAN Secretariat. pp. 177-179.

Babu KM, McCurdy CR, Boyer EW [2008]. Opioid receptors and legal highs: Salvia divinorum and kratom. Clin Toxicol 46(2):146-152.

Boyer EW, Babu KM, Adkins JE, McCurdy CR, Halpern JH [2008]. Self-treatment of opioid withdrawal using kratom (Mitragyna speciosa Korth). Addiction 103(6):1048-1050.

Burkill IH [1935]. A dictionary of the economic products of the Malay peninsula, vol. II. Newport, New Hampshire: Ministry of Agriculture and Co-Operatives, pp. 1480-1483.

Buser GL, Gerona RR, Horowitz BZ, Vian KP, Troxell ML, Hendrickson RG, Houghton DC, Rozansky D, Su SW, Leman RF [2014]. Acute kidney injury associated with smoking synthetic cannabinoid. Clin Toxicol 52(7):664-673.

CDC (Centers for Disease Control and Prevention) [2013]. Acute kidney injury associated with synthetic cannabinoid use-multiple states, 2012. MMWR 62(6):93-98.

CFR. Code of Federal Regulations. Washington, DC: U.S. Government Printing Office, Office of the Federal Register.

DEA (U.S. Department of Justice Drug Enforcement Administration) [2011]. Scheduling update. Microgram bulletin. [http://www.justice.gov/dea/pr/micrograms/2011/mg0111.pdf].

Date accessed: March 2016.

DuPont [2016]. DuPont chemical protective garments and accessories. [http://www.dupont. com/products-and-services/personal-protective-equipment/chemical-protective-garments. html]. Date accessed: March 2016.

EMCDDA (European Monitoring Centre for Drugs and Drug Addiction) [2015]. Kratom (Mitragyna speciosa) drug profile. [http://www.emcdda.europa.eu/publications/drug-profiles/ kratom]. Date accessed: March 2016.

Gerona R (Roy.Gerona@ucsf.edu) [2015]. Private e-mail message to Loren Tapp (ltapp@ cdc.gov). July 22, 2015. 
Grewal KS [1932a]. Observations on the pharmacology of mitragynine. J Pharmacol Exp Ther 46(3):251-271.

Grewal KS [1932b]. The effect of mitragynine on man. Br J Med Psychol 12(1):41-58. Hanapi NA, Ismail S, Mansor SM [2013]. Inhibitory effect of mitragynine on human cytochrome P450 enzyme activities. Pharmacognosy Res 5(4):241-246. doi: 10.4103/09748490.118806 .

Harris CR, Brown A [2013]. Synthetic cannabinoid intoxication: a case series and review. J Emerg Med 44(2):360-366.

Hathaway GJ, Proctor NH [2004]. Proctor and Hughes' chemical hazards of the workplace. 5th ed. Hoboken, NJ: John Wiley and Sons, Inc. pp.17-18 and 308-309.

Havemann-Reinecke U [2011]. Kratom and alcohol dependence: clinical symptoms, withdrawal treatment and pharmacological mechanisms - a case report. Eur Psychiatry 26(Suppl 1):01-50.

Hermanns-Clausen M, Kneisel S, Szabo B, Auwarter V [2012]. Acute toxicity due to the confirmed consumption of synthetic cannabinoids: clinical and laboratory findings. Addiction 108(3):534-544.

Hillebrand J, Olszewski D, Sedefov R [2010]. Legal highs on the Internet. Subst Use Misuse 45(3):330-340.

Jinwala FN, Gupta M [2012]. Synthetic cannabis and respiratory depression. J Child Adolesc Psychopharmacol 22(6):459-462.

Macko E, Weisbach JA, Douglas B [1972]. Some observations on the pharmacology of mitragynine. Arch Int Pharmacodynam Ther 198(1):145-151.

Matsumoto K, Mizowaki M, Suchitra T, Takayama H, Sakai S, Watanabe H [1996]. Antinociceptive action of mitragynine in mice: evidence for the involvement of supraspinal opioid receptors. Life Sci 59(14):1149-1155.

Mir A, Obafemi A, Young A, Kane C [2011]. Myocardial infarction associated with use of the synthetic cannabinoid K2. Pediatrics 128:e1622-e1627.

NIOSH [2010]. NIOSH pocket guide to chemical hazards. Cincinnati, OH: U.S. Department of Health and Human Services, Centers for Disease Control and Prevention, National Institute for Occupational Safety and Health, DHHS (NIOSH) Publication No. 2010-168c. [http://www.cdc.gov/niosh/npg/]. Date accessed: March 2016.

NIOSH [2016]. NIOSH manual of analytical methods (NMAM®). 4th ed. Schlecht PC, O'Connor PF, eds. Cincinnati, OH: U.S. Department of Health and Human Services, Centers for Disease Control and Prevention, National Institute for Occupational Safety and Health, DHHS (NIOSH) Publication 94-113 (August 1994); 1st Supplement Publication 96-135; 2nd Supplement Publication 98-119; 3rd Supplement 2003-154. [http://www.cdc.gov/niosh/ docs/2003-154/]. Date accessed: March 2016. 
Patton AL, Chimalakonda KC, Moran CL, McCain KR, Radominska-Pandya A, James LP, Kokes C, Moran JH [2013]. K2 toxicity: fatal case of psychiatric complications following AM2201 exposure. J Forensic Sci 58(6):1676-1680.

Rosenbaum CD, Carreiro SP, Babu KM [2012]. Here today, gone tomorrow... and back again? A review of herbal marijuana alternatives (K2, spice), synthetic cathinones (bath salts), kratom, salvia divinorum, methoxetamine, and piperazines. J Med Toxicol 8(1):15-32.

Seely KA, Lapoint J, Moran JH, Fattore L [2012]. Spice drugs are more than harmless herbal blends: a review of the pharmacology and toxicology of synthetic cannabinoids. Prog Neuropsychopharmacol Biol Psychiatry 39(2):234-243.

Spaderna M, Addy PH, D’Souza DC [2013]. Spicing things up: synthetic cannabinoids. Psychopharmacology 228(4):525-540.

Streich HT, Rushton WF, Charlton NP [2014]. 164. Death by spice: a case report of mortality following synthetic cannabinoid use. XXXIV International Congress of the European Association of Poisons Centres and Clinical Toxicologists (EAPCCT) 27-30. Clin Toxicol $52(4): 365$.

Suwanlert S [1975]. A study of kratom eaters in Thailand. Bull Narc 27(3):21-27.

Takematsu M, Hoffman RS, Nelson LS, Schechter JM, Moran JH, Wiener SW [2014]. A case of acute cerebral ischemia following inhalation of a synthetic cannabinoid. Clin Toxicol 52(9):973-975.

Tanguay P [2011]. Kratom in Thailand. European monitoring centre for drugs and drug addition, series on legislative reform of drug policies No. 13:1-16. [https://www.tni.org/files/ download/kratom-briefing-dlr13.pdf]. Date accessed: March 2016.

Ward J, Rosenbaum C, Hernon C, McCurdy CR, Boyer EW [2011]. Herbal medicines for the management of opioid addiction: safe and effective alternatives to conventional pharmacotherapy? CNS Drugs 25(12):999-1007. 
Keywords: North American Industry Classification System 928110 (National Security), Nevada, spice lab, synthetic cannabinoids, AB-PINACA, mitragynine, kratom, PPE, illegal drugs, personal protective equipment, respirators, ventilation, law enforcement. 
This page left intentionally blank 
The Health Hazard Evaluation Program investigates possible health hazards in the workplace under the authority of the Occupational Safety and Health Act of 1970 (29 U.S.C. § 669(a) (6)). The Health Hazard Evaluation Program also provides, upon request, technical assistance to federal, state, and local agencies to investigate occupational health hazards and to prevent occupational disease or injury. Regulations guiding the Program can be found in Title 42, Code of Federal Regulations, Part 85; Requests for Health Hazard Evaluations (42 CFR Part 85).

\section{Disclaimer}

The recommendations in this report are made on the basis of the findings at the workplace evaluated and may not be applicable to other workplaces.

Mention of any company or product in this report does not constitute endorsement by NIOSH.

Citations to Web sites external to NIOSH do not constitute NIOSH endorsement of the sponsoring organizations or their programs or products. NIOSH is not responsible for the content of these Web sites. All Web addresses referenced in this document were accessible as of the publication date.

\section{Acknowledgments}

Analytical Support: Jennifer Roberts; Deborah Sammons; Roy Gerona, University of

California, San Francisco; Randox Toxicology Limited; Bureau Veritas North America

Data Management: Denise Giglio

Desktop Publisher: Shawna Watts

Editor: Ellen Galloway

Logistics: Donnie Booher, Kevin Moore

Medical Field Assistance: Deborah Sammons

\section{Availability of Report}

Copies of this report have been sent to the employer and employees at the facility. The state and local health department and the Occupational Safety and Health Administration Regional Office have also received a copy. This report is not copyrighted and may be freely reproduced.

This report is available at http://www.cdc.gov/niosh/hhe/reports/pdfs/2014-0039-3246.pdf.

\section{Recommended citation for this report:}

NIOSH [2016]. Health hazard evaluation report: evaluation of law enforcement agents' potential exposures during a raid of a clandestine "spice" lab. By Ramsey JG, Tapp L, Burr G. Cincinnati, OH: U.S. Department of Health and Human Services, Centers for Disease Control and Prevention, National Institute for Occupational Safety and Health, NIOSH HHE Report No. 2014-0039-3246. 
Delivering on the Nation's promise:

Safety and health at work for all people through research and prevention

To receive NIOSH documents or more information about occupational safety and health topics, please contact NIOSH:

Telephone: 1-800-CDC-INFO (1-800-232-4636)

TTY: 1-888-232-6348

CDC INFO: www.cdc.gov/info

or visit the NIOSH Web site at www.cdc.gov/niosh

For a monthly update on news at $\mathrm{NIOSH}$, subscribe to

$\mathrm{NIOSH}$ eNews by visiting www.cdc.gov/niosh/eNews. 